\title{
Research Paper Marketing analysis of organic and inorganic jaggery in Kolhapur district of Maharashtra
}

See end of the paper for authors' affiliations

Correspondence to : N. M. Malkunje Department of Agricultural Economics and Statistics, College of Agriculture, Kolhapur (M.S.) India Email : nasroddin786@ gmail.com

\section{Paper History :}

Received : 03.06.2017;

Revised : 30.01.2018;

Accepted : 14.02 .2018
ABSTRACT : The present study was a modest attempt to marketing analysis of organic and inorganic jaggeryproduction in the Kolhapur district of Maharashtra in 2011 -12. In marketing of jaggery, three marketing channels were identified in the study area. They were Channel-I: Producer $\rightarrow$ Primary Wholesaler $\rightarrow$ Retailer $\rightarrow$ Consumer, Channel-II: Producer $\rightarrow$ Commission agent $\rightarrow$ Secondary Wholesaler $\rightarrow$ Retailer $\rightarrow$ Consumer and Channel-III: Producer $\rightarrow$ Commission agent $\rightarrow$ Distant Wholesaler $\rightarrow$ Retailer $\rightarrow$ Consumer. The quantity sold through the channel-III was more than channelI and channel-II for both of category. It is also examine that the marketing cost in channel III (Rs. 516.32) was relatively high as compared to channel II (Rs.383.58) and channel I (Rs.330.48) for organic jaggery the same results were observed in case of inorganic jaggery i.e. marketing cost in channel III (Rs. 482.15) was relatively high as compared to channel II (Rs. 352.37) and channel I (Rs. 286.93). This may be due to relatively more transportation, commission, packaging, unloading and loading charges in case of Channel III than Channel II and Channel I. At overall level the price spread was Rs. 988.66 and 939.46 for organic and inorganic jaggery, respectively. The channel wise price paid was the highest as Rs. 1208.69 in channel-III, followed by Rs .981.48 in channel-II and Rs. 775.82 in channel-I in organic jaggery whereas for inorganic jaggery it was Rs. 1158.30 in channel-III, followed by Rs. 916.89 in channel-II and Rs. 743.18 in channel-I, respectively. At overall level marketing efficiency of organic and inorganic jaggery was 127.44 per cent and 128.51 per cent, respectively.

KEY WORDS : Marketing channel, Marketing cost, Price spread, Market margin, Marketing efficiency

How To Cite This Paper : Malkunje, N.M., Lembhe, J.V. and Kharat, H.V. (2018). Marketing analysis of organic and inorganic jaggery in Kolhapur district of Maharashtra. Internat. Res. J. Agric. Eco. \& Stat., 9 (1) : 166-174, DOI : 10.15740/HAS/IRJAES/9.1/166-174. 